\title{
Identification of archaeological charred wood from Ille site, El Nido, Palawan, Philippines
}

\author{
Jane B. Carlos ${ }^{1 *}$, Ramiro P. Escobin ${ }^{2}$, Jennifer Conda², Mario D.R. Ramos², Helen Lewis ${ }^{3}$ And Victor J. Paz ${ }^{1}$
}

\begin{abstract}
Seven charred wood fragments from the archaeological site of Ille in El Nido, Palawan were identified as an undetermined monocot and representatives of the families Caesalpiniaceae, Dipterocarpaceae, and Araucariaceae/Podocarpaceae. Though very few pieces were determined, the results gave a glimpse of the types of woody plants most likely present in the vicinity of Ille, 14,000 to around 4,000 years ago. This report also aims to provide taxonomic identification based on the available literature to serve as baseline information for future use.
\end{abstract}

KEYWORDS: anthracology, archaeobotany, hardwood, softwood, monocotyledon

\section{INTRODUCTION}

The identification of plant remains including seeds, nuts, parenchyma tissues and wood fragments is a critical part of archaeobotany. While the ideal documentation of wood for paleontological analysis involves a critical examination of its three planes, the availability of one section (transverse) as is the case of samples in this study, is deemed very helpful but challenging as a basis for definite taxonomic identification. Once the material is taxonomically known, usually to the family, genus and sometimes to the species level, inferences on the palaeoenvironment, subsistence and other cultural activities in the past can be made.

The study of wood charcoal, or anthracology, has seen its application to archaeology since fragments of charred wood are often recovered from archaeological sites. This has been a long tradition in Europe and the Americas but in Southeast Asia and the Philippines, there are very few studies on this (Dimbledy 1978; Minnis 1978; Pearsall 2000; Balme \& Beck 2002; Escobin et al. 2014; Paz et al. 2009; Ceron et al. 2008). Generally, data from wood charcoal can be used to infer past

${ }^{1}$ Archaeological Studies Program, University of the Philippines, Diliman, Quezon City

${ }^{2}$ Forest Products Research and Development Institute, Department of Science and Technology, Los Baños, Laguna

${ }^{3}$ University College Dublin, Ireland

*Corresponding email: carlosjaneb@yahoo.com, abcarlos1@up.edu.ph

Date Submitted: 02 September 2018

Date Accepted: 25 March 2019 vegetation and human use of woody resources (i.e., as fuel, tools, construction materials). This paper presents an initial analysis of charred wood from the Ille Site in El Nido, Palawan.

\section{The site}

The archaeological site of Ille which is both a cave and a rockshelter is located in Barangay New Ibajay (formerly Dewil), El Nido, northern Palawan. It is about $5 \mathrm{~km}$ inland from the eastern coast of northern Palawan, $118 \mathrm{~m}$ above sea level and has coordinates of $11^{\circ} 11^{\prime} 50^{\prime \prime}$ and $11^{\circ} 12^{\prime}$ north latitude and $11930^{\prime} 15^{\prime \prime}$ and $1193^{\prime} 1^{\prime} 20^{\prime \prime}$ east longitude (ASP 2007). The site is in the base of a karst tower which is about $75 \mathrm{~m}$ high (Figs. 1a, b). It has been surveyed and excavated for the last twenty years since its discovery in 1998 (Dela Torre 1999; Swete-Kelly and Szabo 2002; Solheim 2004; ASP 2007; Paz et al. 2011; Paz et al. 2016).

The Ille site has radio carbon dates ranging from 14,000 to 4,000 B.P. (before present or years ago, y.a.) (Lewis et al. 2008). The upper layer is a cemetery up until probably the 19th century and below this is an occupation site with a shell midden dated from 7,000 to 5,000 y.a. (Szabo et al. 2004) (see Fig. 2). Below this are layers with combustion features where charred animal bones were found indicating a place where ancient people cooked and consumed animals (Ochoa 2009). These lower layers were dated from 14,000 to 8,000 y.a. A cremation burial in these layers was directly dated to 9,000 y.a. (Lewis et al. 2008).

The Ille site has radio carbon dates ranging from 14,000 to 

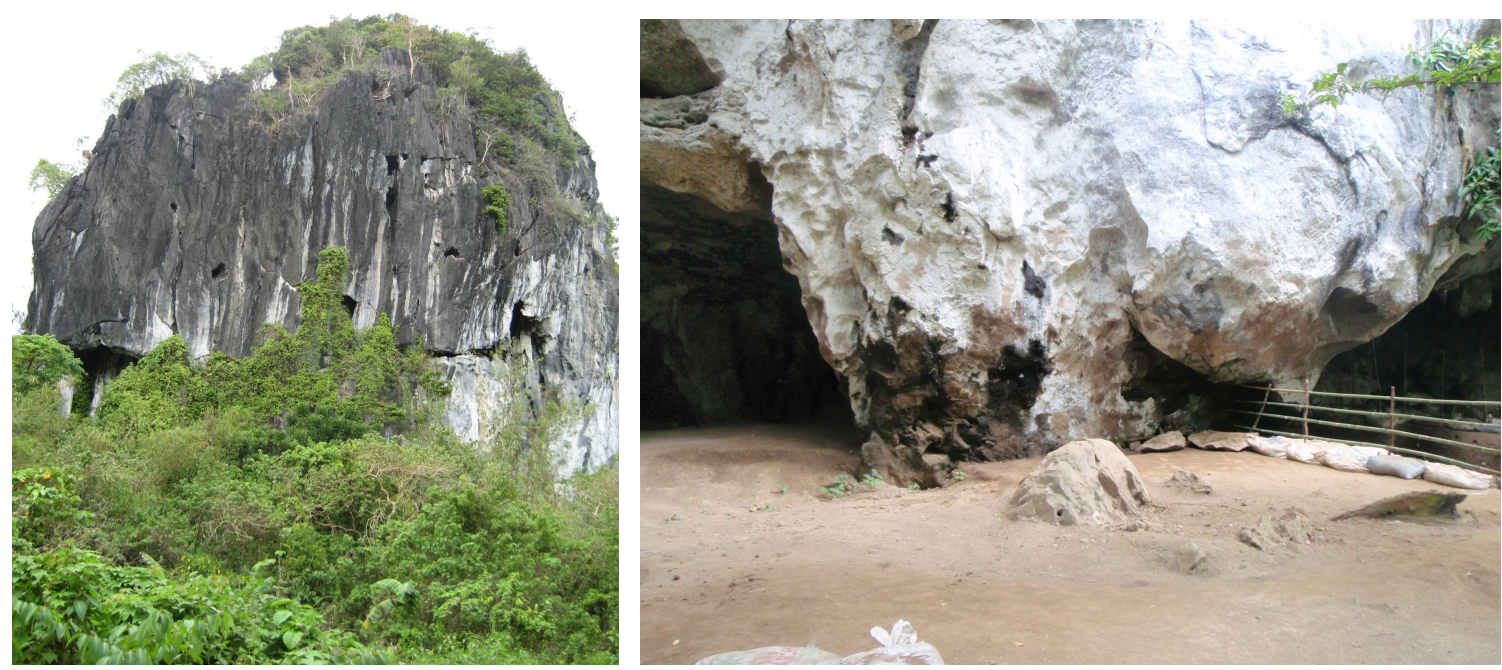

Figures 1 a-b. Ille karst (a) and (b) Ille platform (photos by V. Paz \& J. Carlos)

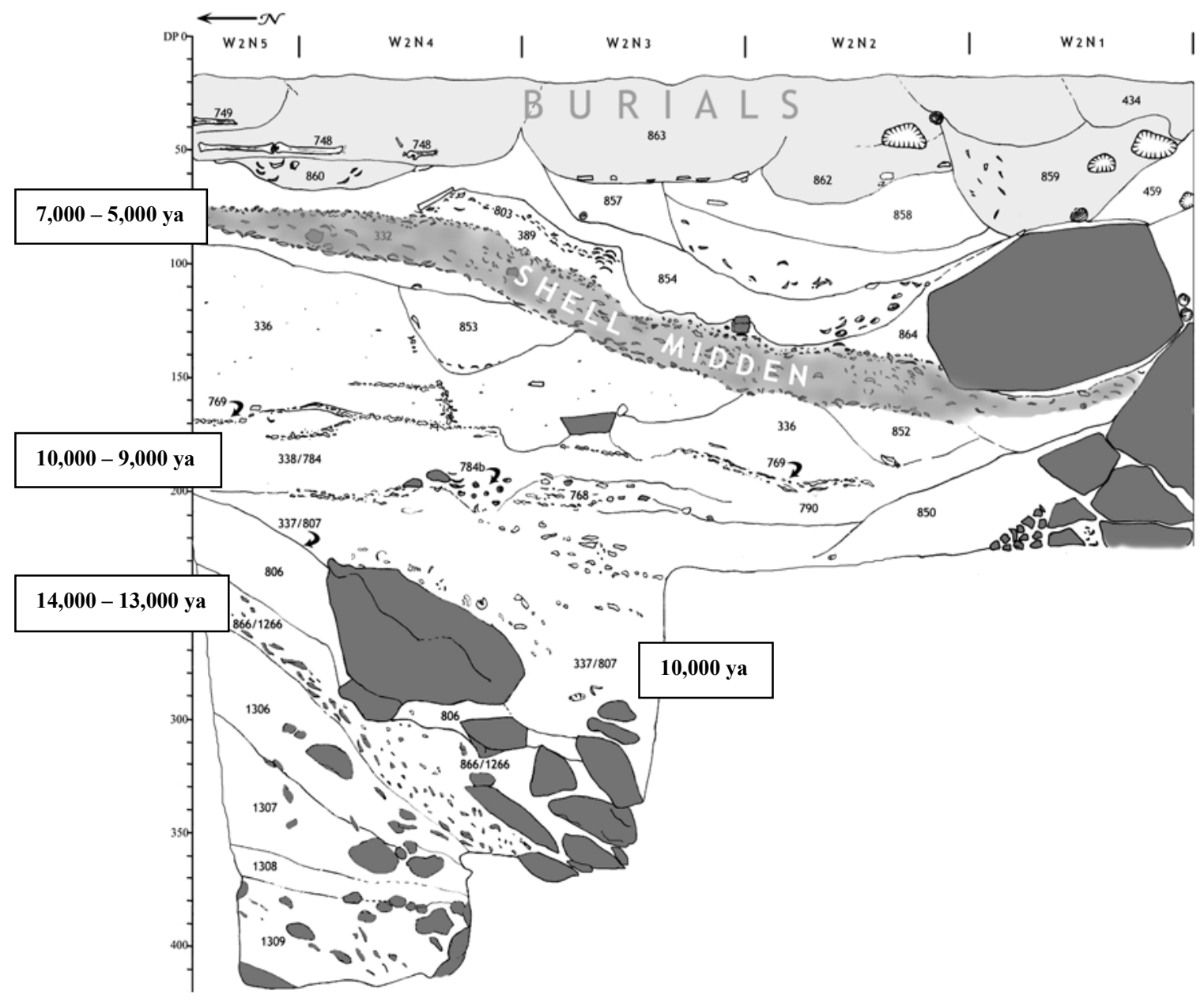

Figure 2. East wall stratigraphic profile (from Lewis et al. 2008) 
4,000 B.P. (before present or years ago, y.a.) (Lewis et al. 2008). The upper layer is a cemetery up until probably the $19^{\text {th }}$ century and below this is an occupation site with a shell midden dated from 7,000 to 5,000 y.a. (Szabo et al. 2004) (see Fig. 2). Below this are layers with combustion features where charred animal bones were found indicating a place where ancient people cooked and consumed animals (Ochoa 2009). These lower layers were dated from 14,000 to 8,000 y.a. A cremation burial in these layers was directly dated to 9,000 y.a. (Lewis et al. 2008).

While many fragments of charred wood have been recovered from the Ille Site, this paper presents the identification of a few charred wood recovered from layers dating from 14,000 to around 4000 y.a.. The most common state of preservation of plant remains is through carbonization which renders anatomical features to be still recognizable, enough for taxonomic identification. Experimental charring of contemporary wood samples has proven this (Carlos et al. in press; Braadbart \& Poole 2007).

\section{MATERIALS AND METHOdS}

\section{Recovery of Plant Remains}

The main method of recovery for plant remains from the Ille Site was through bucket flotation where excavated sediment was washed in batches of 1.5-4.5 L (Carlos 2010). The water used was from the nearby deep well and stream which was filtered with a fine cloth to avoid contamination from modern materials. Plant remains like seeds, wood fragments and other plant tissues are light materials which floated upon washing of the sediment. These floating materials were then collected in a fine cloth, hanged to dry then sorted with a low power microscope. The seeds, wood fragments, and other plant parts and tissues were separated and then placed in small plastic tubes labelled with their corresponding proveniences.

\section{Preparation of Samples for Imaging}

Exposure of the fresh transverse surfaces of the charred wood was done through hand snapping. A blade cutter was not used since the cutting action would have rendered the features of the wood indistinct and damaged. The samples were then mounted on Scanning Electron Microscope (SEM) stubs using carbon tape as adhesive. The samples were not sputtered with any metal coating, which somehow compromised the image quality but not the potential of the samples for radio carbon dating in future studies.

SEM imaging was done at the facilities of Forest Products Research and Development Institute (FPRDI) at Los Baños, Laguna using the FEI Inspect model S50 SEM.
The identification of the archaeological samples was based on their diagnostic anatomical characters like vessels, parenchyma and rays which were observable in the transverse section. The comparison of these features to published works and a reference collection is detailed in the results section. Identification was also aided by the floristic inventory conducted by Bandong $(2005,2006)$ in the Dewil valley.

\section{RESULTS AND DISCUSSION}

SEM images of seven charred wood fragments were identified as belonging to the Caesalpiniaceae, Dipterocarpaceae, and Araucariaceae/Podocarpaceae, as well as an unknown monocot.

\section{1) Caesalpiniaceae - Intsia sp.}

The two archaeological samples have solitary vessels and some in multiples of 2. The vessels were sparse, falling within the vessel frequency range of 2.5-5 vessels $/ \mathrm{mm}^{2}$ of Intsia species. Paratracheal axial parenchyma is lozengealiform (with broad and short wings) and terminal (Ogata et al. 2008). Lozenge-aliform parenchyma refers to parenchyma cells surrounding or attached to one side of the vessels with lateral extensions forming a diamond shaped outline (Wheeler et al.:272).

There was no tangential view of the samples but the 1-2 cell wide rays were observable, with more 2-cells (and one uniseriate) which is typical of Intsia bijuga (Colebr.) O.Kuntze as described in Ogata et al. (2008). The crystals in the axial parenchyma cells, typical of I. bijuga, however, were not observable in the samples. But according to Wheeler et al. (1989:312), "when identifying an unknown, using absence of crystals is not recommended because crystals are of sporadic occurrence in many other taxa."

The samples displayed narrow, almost indistinct parenchyma bands that appear to extend from the ends of the broad wings of the axial parenchyma. Wheeler et al. (1989: 276) described the axial parenchyma of I. bijuga as occurring "in marginal or seemingly marginal bands" that refers to "parenchyma bands which form a more or less continuous layer of variable width at the margins of a growth ring or are irregularly zonate".

Intsia is a small genus of trees with good timber found in tropical Africa, Asia, and Polynesia and are usually seen in coastal areas and in lowland tropical rain forests (Burkill 1966). Intsia spp. are also used for their dye and medicinal properties (yellow dye/resin) and the fruits of I. retusa (Kurz) Kuntze are poisonous but when heated, shelled and soaked in water for 3-4 days, they serve as a famine food in eastern Malaysia (Burkill 1966:1263). 

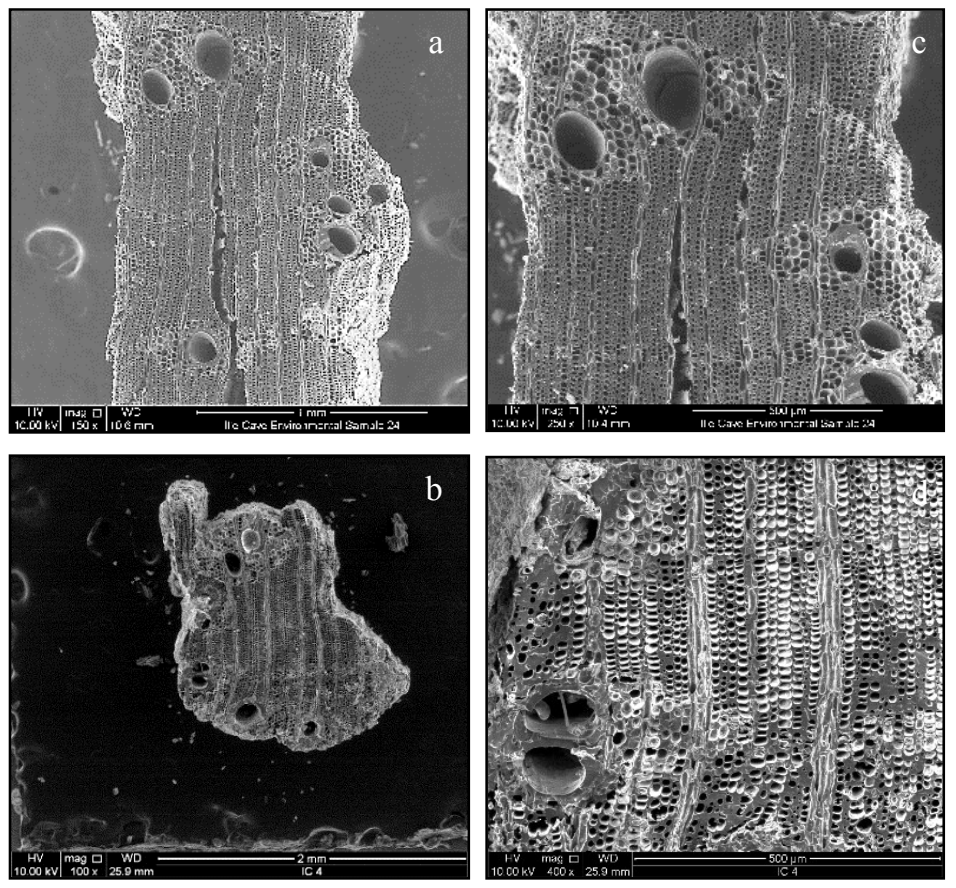

Figure 3 a-d. Intsia sp.

There are three to four species of Intsia recorded in the Philippines - I. bijuga (Colebr.) O.Kuntze, I. bakeri (Prain) Prain, I. retusa (Kurz) O.Kuntze and I. palembanica Miq. (Rojo 1999; Burkill 1966; Merrill 1912). I. retusa is now classified as a synonym of I. bijuga and I. bakeri as a synonym of $I$. palembanica (www.catalogueoflife.org). I. bijuga (ipil) is "usually found along seashores, in inland forests up to c. $600 \mathrm{~m}$ altitude" and Intsia palembanica "is widespread in coastal regions, edges of seasonal swamps, on inundated lands, in lowland primary or older secondary forests from sea level to 850m altitude" (Burkill 1966:1263). Interestingly, I. palembanica is so far found only in Palawan and is known as Palawan ipil (Rojo 1999).

The botanical survey made around Ille Cave showed that $I$. bijuga is the only species present in the immediate vicinities (Bandong 2006). It is possible, however, that the other species of Intsia could have been present in ancient times.

The first sample (Fig. 3a \& c) comes from context 784, a layer with radiocarbon dates of $10,000-9,000$ y.a. while the second sample is from context 777 , a spit in a layer that is around 4,000 years of age.

\section{2) Caesalpiniaceae - cf. Koompassia sp. [Fig. 4]}

The archaeological sample had solitary vessels with some in radial multiples of 2 . The axial parenchyma was lozengealiform to confluent; the wings were broad. There was no tangential image of the sample but the transverse section showed the rays to be clearly uniseriates. This sample was further differentiated from the previous two samples determined as Intsia sp. by its wavy confluent bands of parenchyma.

The literature on Koompassia excelsa (Becc.) Taub. varies in terms of ray width - some say it is $2-5$ seriate and yet another reference say it is exclusively uniseriate (Ogata et al. 2008). Following Paz (2001), the archaeological sample is identified as cf. Koompassia sp.; the prefix cf. means the sample compares favorably or 'looks like' Koompassia sp.

Koompassia is a very small genus of trees with three species - one in New Guinea and two in tropical Asia (La Frankie 2010; Burkill 1966). Koompassia trees are used for timber which are very heavy and hard but not durable; the bark has medicinal properties while the sap is poisonous (Burkill 1966). K. malaccensis Benth. is "difficult to work and is little used except for firewood and charcoal" (Burkill 1966: 1305). These trees are not very abundant, usually found in primary forests on foothills and in valleys near streams (Rojo 1999; Burkill 1966). K. excelsa was recently recorded in Palawan (La Frankie 2010; Rojo 1999).

The charred wood fragment came from the little sediment within the cremation burial (context 758). This burial is directly dated at 9,500-9,000 y.a. Perhaps the charred sample that looks like Koompassia sp. was part of the fuel used in the burning of the cremation.
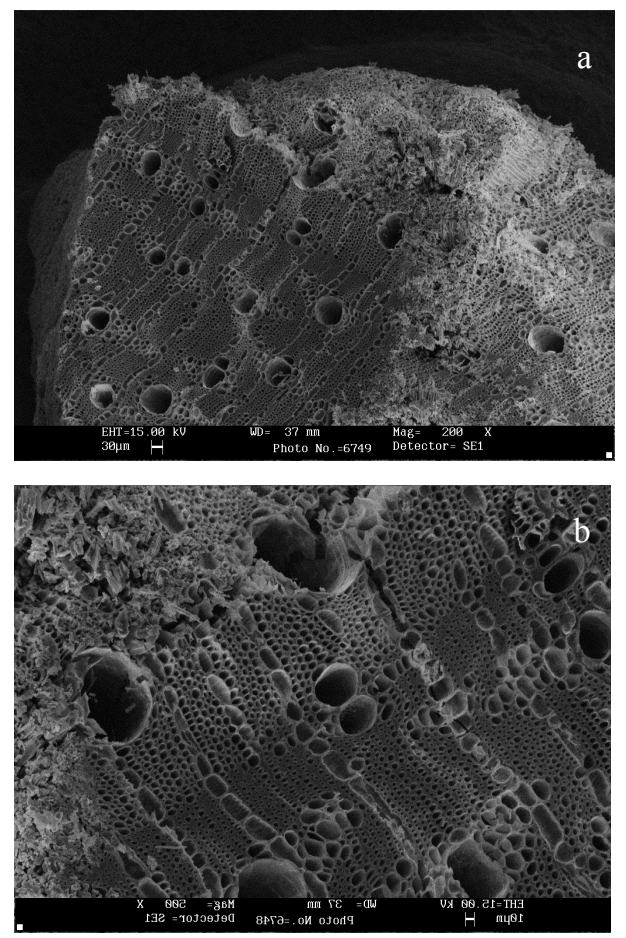

Figures 4 a-b. cf. Koompassia sp. 


\section{3) Dipterocarpaceae - cf. Vatica sp.}

The sample had round to oval pores or vessels that are mostly solitary with a few in multiples of 2 . The echelon and/or diagonal arrangement of some pores was observed in the sample. There were varied sizes of the vessels (ranging in diameter from about 70-125 um) but the smallest ones were most likely resin ducts that are diffused among fibers which is characteristic of Vatica spp. (Daracan \& Calapis 2013; Ogata et al. 2008; Meniado et al. 1975). The frequency was at least 15 vessels $/ \mathrm{mm}^{2}$ which is within the range of 11-66 vessels/ $\mathrm{mm}^{2}$ found in Vatica spp. (Ogata et al. 2008). The rays were not distinct in the image but there seems to be thick and narrow rays that are characteristic of Vatica spp. (Ella et al. 2009; Ogata et al 2008; Meniado et al. 1975).

Axial parenchyma is diffused in Vatica ssp. and this genus has indistinct growth rings. The vessels are diffuse porous with a diagonal and/or radial pattern which is the same as the archaeological sample. This sample is therefore identified as cf. Vatica sp. The sample comes from context 806, a layer dated to the terminal Pleistocene (12,000 to 10,000 y.a.).

Vatica is a genus of trees with seven species in the Philippines (La Frankie 2010; Rojo 1999). This genus is resinous, its wood varies from soft and light to very hard and very heavy, depending on the species, and is usually utilized for timber (La Frankie 2010; Burkill 1966). Vatica spp. are found in the lowlands, hill forests and near streams (La Frankie 2010; Rojo 1999; Burkill 1966).

\section{4) Araucariaceae / Podocarpaceae}

Two charred wood fragments (Figs. $6 a-b)$ were devoid of vessel elements or vascular tissues; only fibers and tracheids were observed so these were determined as softwood

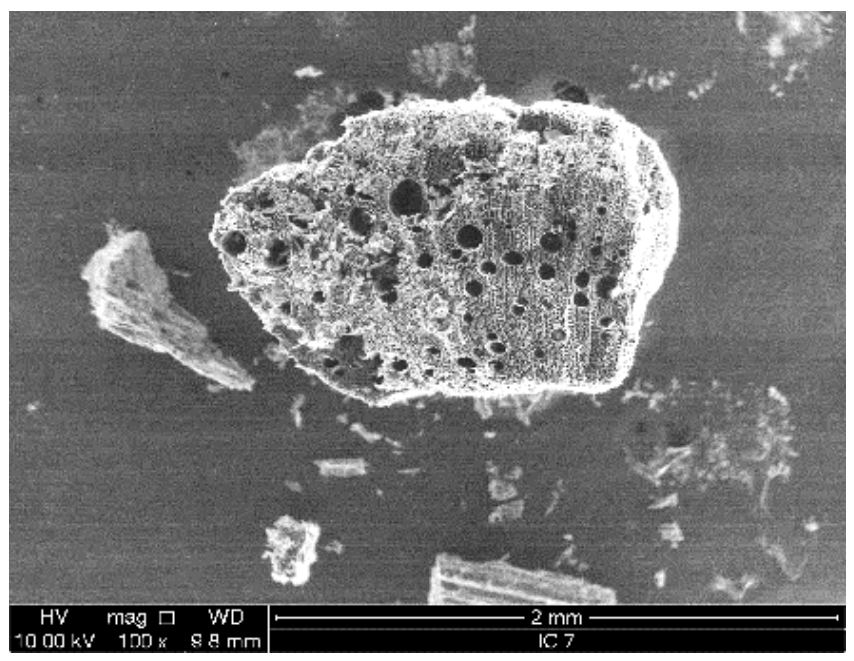

Figures 5. cf. Vatica sp.

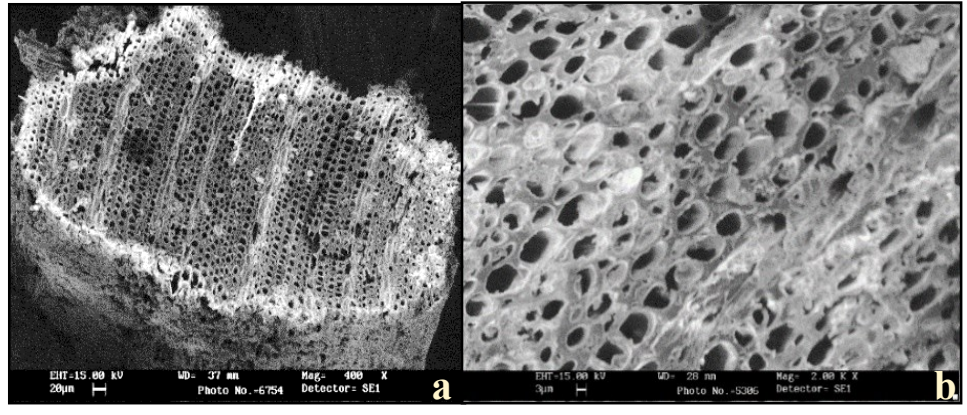

Figures 6 a-b. Araucariaceae / Podocarpaceae

(Banning 2000). The samples had no visible growth rings but this could be due to the small size of the samples. No resin canals were found, indicating that the wood fragments were either from the families Araucariaceae or Podocarpaceae and not the Pinaceae. These are the only three families of gymnosperms or conifers present in Southeast Asia and the Pacific (Ogata et al. 2008).

Axial parenchyma was not observed and this could be due to the removal of contents representing axial parenchyma in archaeological wood (Richter et al. 2004). While these contents can be confirmed in the longitudinal section, unfortunately, only an image of the transverse section is available. So, differentiating Araucariaceae from Podocarpaceae is a challenge since the former has no axial parenchyma while the latter has abundant axial parenchyma cells (Ogata et al. 2008). Although in some species of Podocarpaceae, this feature is also almost absent or rare (Ogata et al. 2008).

The rays of the samples were 2-3 cells wide so we determined that the sample was not Dacrydium or Phyllocladus (Podocarpaceae) since these two genera have exclusively uniseriate rays. Uniseriate rays also commonly occur in Agathis sp. (Araucariaceae) (Ogata et al. 2008). Due to lack of other observable features, the determination of the sample was placed at either belonging to the families Araucariaceae or Podocarpaceae. Both samples were derived from context 866, a layer dating from 14,000 to 13,000 y.a.

Podocarpaceae are composed of about 5-7 genera present in the Philippines while Araucariaceae has 3 genera (La Frankie 2010; Ogata et al. 2008; Rojo 1999). There are about 18 Podocarpaceae species in Southeast Asia with 2 species endemic to the Philippines (Rojo 1999).

\section{5) Monocotyledon}

The features in this sample were fused but there were at least two vascular bundles with the sclerenchyma cells ('cap') and metaxylem (or the large vessels or pores) that are 
Table 1. Summary of Identifications

\begin{tabular}{|c|c|c|c|c|}
\hline Identified Charred Wood & Context No. & $\begin{array}{c}\text { Calibrated Years B.P. } \quad \text { (or } \\
\text { years ago) }\end{array}$ & Laboratory No. & $\begin{array}{c}\text { Relative Dates } \\
\text { (years ago) }\end{array}$ \\
\hline \multirow[t]{2}{*}{ Intsia sp. } & 777 & & & $\sim 4000$ \\
\hline & 332 & $7253-5908$ & ANU-11869 & \\
\hline monocotyledon & 745 & & & $7000-5000$ \\
\hline \multirow[t]{2}{*}{ cf. Koompassiasp. } & 758 & $9425-9280$ & OxA-15982 & \\
\hline & 769 & $9964-9701$ & OxA-15766 & \\
\hline \multirow[t]{2}{*}{ Intsia sp. } & 784 & $10006-9994$ & OxA-15818 & \\
\hline & 807 & $10425-10283$ & OxA-16657 & \\
\hline cf. Vatica sp. & 806 & & & $12000-10000$ \\
\hline \multicolumn{5}{|l|}{ Araucariaceae or } \\
\hline Podocarpaceae & 866 & $14116-13820$ & OxA-16666 & \\
\hline
\end{tabular}

characteristic of monocotyledons (Escobin et al. 2015). There are many woody monocots from several families (i.e., Arecaceae, Poaceae) and with this sample's condition, it can only be identified as an undetermined monocot.

The monocot sample comes from context 745, a crushed shell layer that is part of the shell midden (c. 332) dated from 7,000 to 5,000 y.a.

\section{DISCUSSION}

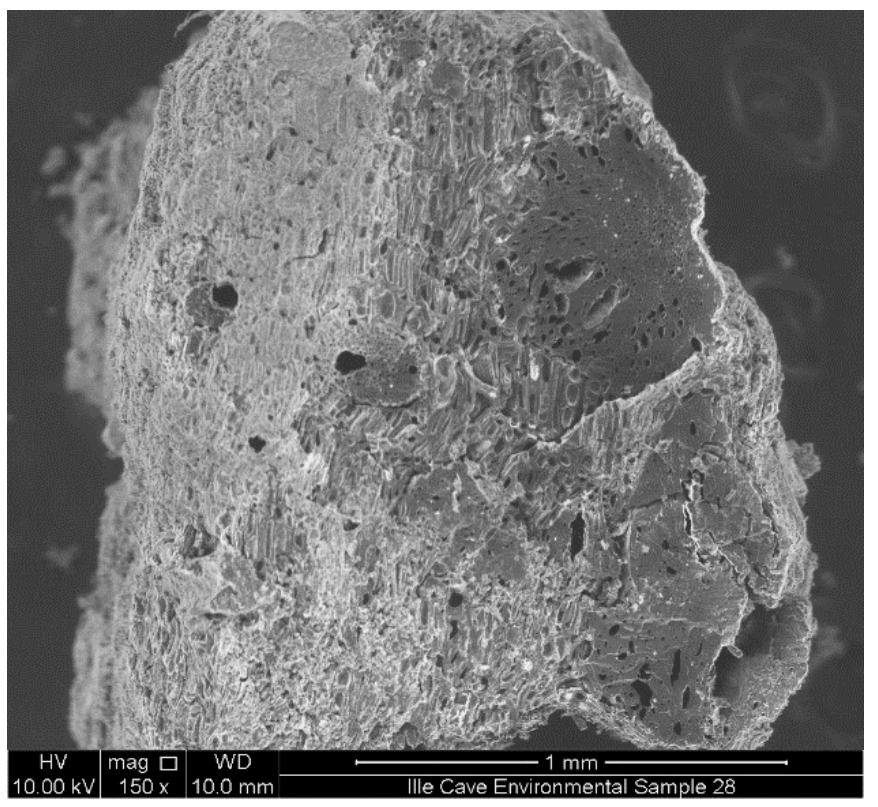

Figure 7. Monocotyledon from context 745 of Identifications
From a previous macrobotanical study (Carlos 2010) we know that the vegetation around Ille during the terminal Pleistocene (and older) was grassland and became forested towards the Holocene. This is supported by studies on faunal remains and guano (Ochoa 2009; Bird et al. 2007). While the studied materials were very few, perhaps the presence of the dipterocarp (cf. Vatica sp.) and the softwood samples (Araucariaceae / Podocarpaceae) in the terminal Pleistocene layers, the deepest layers that are part of the habitation phase in the Ille site (ASP 2007), are indicative of a developing forest. Dipterocarps dominate and generally characterize Southeast Asian forests (La Frankie 2010). The surveys done by Bandong $(2005 ; 2006)$ have recorded the presence of a few trees of Dipterocarpus grandiflorus Blanco and Vitex parviflora Jussieu and it suggested that the original vegetation must have been a forest, specifically a lowland dipterocarp forest.

Going into the early Holocene (9,000 y.a.), we find Caesalpiniaceae wood (cf. Koompassia sp. and Intsia sp.) that were also forest trees. These early Holocene layers were actually burnt deposits where a series of combustion features and cremated burials were found. Reddish rocks that appear to have been burnt were also present here and these could have been used as hearth stones. Charred animal bones in fragments were likewise recovered. Considering this context, it is likely that the charred wood fragments identified were utilized as fuel for these burning activities, especially cf. Koompassia sp., found within the cremation burial, which could have been part of the fuel wood for burning the human remains.

Further into the Holocene (7,000 to around 4,000 y.a.), another Intsia sp. charcoal was detected along with a monocot wood. Many species of woody monocots thrive in 
tropical settings (i.e., bamboo, rattan, vines, coconut and other palms) and ethnographically, these are often utilized for tools, cordage, construction materials, among many other uses. Though not taxonomically identified, the determination of this plant type was significant since it has always been assumed that these plant types were also used in antiquity. What is needed now is to further pursue its identification with the aid of a robust reference collection. Also, the limitation of images available (which is due to the small size of the samples), showing only the transverse section of the materials is a factor in the taxonomic identification of the archaeological samples.

\section{CONCLUSIONS AND RECOMMENDATIONS}

The identified samples in this study, from layers dated from 14,000 to around 4,000 y.a., are significant in giving us a glimpse of the woody plants that most likely existed in the vicinity of Ille Cave. From the families Caesalpiniaceae (Intsia and cf. Koompassia), Dipterocarpaceae (cf. Vatica) and Araucariaceae/Podocaraceae, there are species that are either endemic, native or indigenous to the Philippines so their presence in antiquity is very probable. But still, we cannot really be certain since we cannot discount the possibility that these small fragments are remnants of tools, weapons or even boats, among other things, that could have been brought to the site. If these were really collected nearby and utilized as fuel, then this gives us an idea of the local flora. Generally, fuel wood, being bulky and heavy, are collected from around or nearby a site (Thompson 1996).

That there is a variety of wood in the site - hardwood, softwood and monocot is interesting as it hints at the variety of plants that could have been around Ille during a period when it was generally grassland then later forested.

The identification of small charred wood fragments presents a challenge especially when only a section of the material, instead of three sections (transverse, tangential and radial), is available. The difficulty lies in exposing fresh surfaces of the small and fragile archaeological samples. Diagnostic features such as ray length or width, presence or absence of cell contents and crystals are clearly observed in tangential and/or radial sections only so ascertaining the taxonomic identity of the materials is not easy.

The identification of charred wood in the Ille Site is promising and full of implications. Binomial identification is just the first step, the implications of the presence of specific taxa presents opportunities for interpretations on past environments and human-plant relationships. But caution should be exercised especially when only a few samples have been identified. In the case of Ille samples, the identified charred wood can only hint at the past environment and cultural practice in the past. This study is just a preview of the materials from Ille; analysis of more charred wood from this site will be done and could reinforce the current data.

\section{ACKNOWLEDGEMENTS}

We would like to thank Mr. Fernando C. Pitargue, Jr. of the Forest Products Research and Development Institute; Palawan Council for Sustainable Development (PCSD); the British Academy; NERC/AHRC Orads Programme; the Coral Bay and Rio Tuba Nickel Mining Co.; National Museum of the Philippines, and the good people of Brgy. New Ibajay, El Nido, Palawan.

\section{LITERATURE CITED}

Archaeological Studies Program (ASP), 2007. The 2007 Season of the Palawan Island Palaeohistoric Research Project: A Partial Report.

Balme, J. \& W. Beck, 2002. Starch and charcoal: Useful measures of activity areas in archaeological rockshelters. Journal of Archaeological Science, 29: 157 $-166$.

Bandong, R.M., 2005. Initial Report on the Flora of the Palawan Ille Cave and Vicinity. Manuscript. University of the Philippines, Archaeological Studies Program.

Bandong, R.M., 2006. Report on the Flora of the Palawan Ille Cave and Vicinity. Manuscript. University of the Philippines, Archaeological Studies Program.

Banning, E. B., 2000. The Archaeologist's Laboratory: The Analysis of Archaeological Data.

USA: Springer.

Bird, M.I., E.M. Boobyer, C. Bryant, H.A. Lewis, V.J. Paz \& E. Stephens, 2007. A long record of environmental change from bat guano deposits in Makangit Cave, Palawan, Philippines. Earth and Environmental Science Transactions of the Royal Society of Edinburgh, 98: 5969.

Braadbaart, F. \& I. Poole, 2008. Morphological, chemical and physical changes during charcoalification of wood and its relevance to archaeological contexts. Journal of Archaeological Science, 35: 2434-2445.

Burkill, I.H., 1966. A Dictionary of the Economic Products of the Malay Peninsula. Kuala Lumpur: Ministry of Agriculture and Co-operatives.

Carlos, J., 2010. Inferring Subsistence Patterns at Ille Cave: The Macrobotanical Evidence. Master's thesis. University of the Philippines, Archaeological Studies Program.

Carlos, J., R. Escobin, M. Ramos, R. Cortez, Jr., J. Conda \& V. Paz, In press. A charred state: Documenting gross and anatomical changes in wood. Philippine Forest Products Journal. 
Ceron, J., M. Eusebio, M. Herrera, E. Lim, P. Roa \& E. Wright, 2008. "The Wooden posts of Opol church ruins, Misamis Oriental" In KAPI Conference. National Commission for Culture and the Arts, Intramuros, Manila.

Daracan, V. \& R. Calapis, 2013. Laboratory Manual in FPPS 11. College of Forestry \& Natural Resources, University of the Philippines Los Baños.

Dela Torre, A., 1999. Brief report: Archaeological excavation at Ille Cave Site (IV-1998-P), New Ibajay (formerly Dewil), El Nido, Palawan (Jan 19 - Feb 2, 1999).

Dimbleby, G.W., 1978. Plants and Archaeology. $2^{\text {nd }}$ ed. London: Humanities Press International.

Ella, A.B., J.M. Meniado, R.P. Escobin, M.M. Maruzzo \& W.M. America, 2009. Anatomical Identification Handbook of Philippine Dipterocarps. College, Laguna, Forest Products Research and Development Institute and International Tropical Timber Organization.

Escobin, R.P., W.M. America, F.C. Pitargue, Jr. \& J.M. Conda, 2015. Revised Wood Identification Handbook for Philippine Timbers Volume 1. Department of Science and Technology - Forest Products Research and Development Institute, College, Laguna. 320p.

Escobin, R.P., J.M. Conda, J.B. Carlos \& J.R. Ceron, 2014. Wood identification \& its application to archaeology. Philippine Forest Products Journal, 5: 49-57.

Flora Malesiana Revision on the Family Caesalpiniaceae; Catalogue of Life: www.catalogueoflife.org

La Frankie, J.V. Jr., 2010. Trees of Tropical Asia: An Illustrated Guide to Diversity. Philippines: Black Tree Publications, Inc.

Lewis, H., V. Paz, M. Lara, H. Barton, P. Piper, J. Ochoa, T. Vitales, J. Carlos, T. Higham, L. Neri, V. Hernandez, J. Stevenson, E. Robles, A. Ragragio, R. Padilla, W. Solheim II \& W. Ronquillo, 2008. Dating and interpreting terminal Pleistocene to mid Holocene cave occupation and an early cremation burial from Palawan, Philippines. Antiquity 82 (316): 318-335.

Meniado, J.A., F.N. Tamolang, F.R. Lopez, W.M. America \& D.S. Alonzo, 1975. Wood Identification Handbook. Vol.1. Manila: Government Printing Office.

Merrill, E.D., 1912. A Flora of Manila. Manila: Bureau of Printing. Department of the Interior, Bureau of Science.

Minnis, P.E., 1978. Paleoethnobotanical indicators of prehistoric environmental disturbance: a case study. In: Ford, R.I., M.F. Brown, M. Hodge \& W.L. Merrill, (ed.), The nature and status of ethnobotany, Museum of Anthropology, University of Michigan Anthropological Paper. No. 67, pp. 347-366.

Ochoa, J., 2009. Terrestrial Vertebrates from Ille Cave, Northern Palawan, Philippines. Master's thesis. University of the Philippines - Archaeological Studies Program.

Ogata, K., T. Fuji, H. Abe \& P. Baas, 2008. Identification of the Timbers of Southeast Asia and the Western Pacific.
Hiyoshidai: Kaiseisha Press.

Paz, V., 2001. Archaeobotany and Cultural Transformation: Patterns of Early Plant Utilization in Northern Wallacea. $\mathrm{PhD}$ dissertation. University of Cambridge.

Paz, V., H. Lewis, J. Carlos, L. De Castro, M. Lara, F. Claravall, A. Favereau, H. Xhauflair \& V. Hernandez, 2016. Palawan Island Palaeohistory Research Project: Report on the 2016 Season.

Paz, V., W. Ronquillo, H. Lewis, J. Carlos, V. Hernandez, E. Robles, Y. Balbaligo, J. Ochoa, M. Lara, A. Ragragio, A. Leplongeon \& W. Solheim II, 2009. Palawan Island Palaeohistoric Research Project: Report on the $2009 \mathrm{EI}$ Nido Field Season.

Paz, V., W. Ronquillo, H. Lewis, E. Robles, V. Hernandez, J. Carlos, A. Ragragio, M. Lara, N. Amano, S. O'Donnell, C. Manalo, M. Herrera, J. Ochoa, D. Stojanovski \& W. Solheim II, 2011. Palawan Island Palaeohistoric Research Project Report on the 2011 El Nido Field Season.

Pearsall, D., 2000. Paleoethnobotany. A Handbook of Procedures. 2nd ed. New York: Academic Press.

Richter, H.G., D. Grosser, I. Heinz \& P.E. Gasson (ed.), 2004. IAWA list of microscopic features for softwood identification. IAWA Journal, 25 (1):1-70.

Rojo, J.P., 1999. Revised Lexicon of Philippine Trees. College, Laguna: Forest Products Research and Development Institute, Department of Science and Technology.

Solheim, W.G., 2004. Excavations of Ille Rock Shelter, Palawan, Philippines (Preliminary Report). Manuscript. Archaeological Studies Program.

Swete-Kelly, M. C. \& K. Szabo, 2002. Archaeological Excavation at Ille Cave, New Ibajay, El Nido, Palawan (April 2002 - Eastern Trench). Test Pit 1 (1):17-24.

Szabo, K., M.C. Swete-Kelly \& A. Peñalosa, 2004. Preliminary results from excavations in the eastern mouth of Ille Cave, northern Palawan. In Paz, V. (ed.), Southeast Asian

Archaeology, The University of the Philippines Press, Quezon City. pp. 209-224.

Thompson, G. B., 1996. Subsistence \& Environment: The Botanical Evidence, The Biological Remains. Part II. Vol. IV. The Excavation at Khok Phanom Di. The Society of Antiquaries of London.

Wheeler, E.A., P. Baas \& P.E. Gasson, (ed.), 1989. IAWA list of microscopic features for hardwood identification. IAWA Bulletin 10 (3):219-332. 